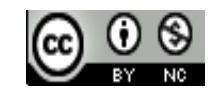

Journal of Education, Teaching, and Learning is licensed under

A Creative Commons Attribution-NonCommercial 4.0 International License.

\title{
ANALYSIS OF INTELLECTUAL CAPITAL DEVELOPED BY ECONOMIC Teachers in Pontianak City State High School
}

\author{
Maria Ulfah \\ UNTAN, Pontianak, Indonesia \\ E-mail:mariafkip@yahoo.co.id
}

\begin{abstract}
This study aims to describe the intellectual capital developed by economic teachers in Pontianak City State High School. The approach used in this study is descriptive qualitative. Data were collected from 10 economic teachers from Pontianak City High School. Data analysis uses descriptive qualitative techniques while data collection uses interviews, observation, and documentation as well as field notes/log book. Intellectual capital developed by economic teachers to improve the quality of graduates by conducting interviews with teachers on the development of intellectual capital, as well as conducting interviews with students and principals as cross-check data. In addition, the researcher also observed the teacher's activities in developing intellectual capital. The results showed that: (1) Intellectual capital developed by economic teachers at Pontianak City Public High School was in the form of competencies, namely MGMP activities, mutual respect, adjusting and helping the work completed assigned by superiors to fellow teachers. Whereas in the form of commitment is trust in the PGRI organization. To control the work developed by the economic teacher by means of independence and freedom of the teacher in making learning plans, controlling the learning and decisionmaking processes during the learning process.
\end{abstract}

Keywords: Economic; Intellectual Capital; High School Teachers

\section{INTRODUCTION}

Human resources are an integral part of the management process of business and public organizations including teachers as human capital resources in the management of educational organizations. The role of human resources in performance constellations pervades each level of the organization to be the main concern and weapon facing various increasingly competitive demands. Organizational pressures in the industrial revolution era include increasing information requirements due to technological changes, changes in economic policies, labor, and demands for quality with various strict requirements. As an illustration, management of organizations within the school environment is faced with quality issues, namely having to meet 8 educational standards which are indicators of school quality and performance. At present, the issue of quality and performance of education in the school environment is a critical issue of national education.

Management of school organizations, especially $85 \%$ of Senior High Schools (SMA)/Madrasah Aliah (MI), State High Schools (SMK) in Pontianak, are indeed faced with quality problems as an important part of performance indicators. Mastery of teachers in most basic competencies (KD) is still weak, teacher mastery of graduate competency standards (SKL) is not optimal, the evaluation system has not referred to the measurement techniques of students. Even though the problems of $\mathrm{KD}$ and SKL are indicators of the Indonesian National Education Standards which are the responsibility of education human resources, especially teachers. Thus, Human Resource Development is urgently needed through Education (Djaali, 2012:2).

Based on the results of the Average National Examination The scores of students in high school subjects in the National Examination in Pontianak in the last two years have decreased in quality, even though the number of graduates has increased. This is in accordance with what was said by the Chairperson of the West Kalimantan National Examination Committee Kusnadi (Antara Kalbar), saying there was a decline in the results of the National Examination at the SMA/SMK/MA level in the province this year compared to 2016. Kusnadi gave an example, the decline in value occurred in the average value of Indonesian language subjects for SMA/MA. The value obtained was 68.82 , the value category $\mathrm{C}$, then, for Social Sciences majors, for example, the average score obtained by students was 58.21 with category C. This included in economic subjects. "At present, what can be seen from the national examination scores is only the average score 
for the subjects," he said. The decline in the value of these subjects, especially Economics, of course, leads to the value of the National Examination which is no longer used as a graduation standard which causes students not to be motivated to learn in facing the National Examination. In addition, of course, the role of the teacher is needed as a motivator to improve performance obtained from the ability to portray intellectual capital.

The normative idea has assumed that intellectual capital produces better performance. An important issue in intellectual capital is to ensure the suitability of individuals to present standards, eliminate uncertainty, and increase the predictability of individual behavior in the workplace (SungChoon and Scott, 2015: 36).

The contribution of intellectual capital, especially by school institutions. Some principals, teachers, and other school residents have not yet known and understood intellectual capital in schools. Some of them already understand it, but don't know how to make the most of it. Intellectual capital owned by the school can be used to help schools in an effort to build school quality so that school quality is achieved to the fullest. Existing phenomena show that in some schools teachers are less able to develop intellectual capital that exists between them and their partners.

The results of the study of Sukarno and Ardyanfitri (2016: 61) say that intellectual capital is able to contribute significantly to the performance of teachers in several high schools in Sidoarjo. Intellectual capital to build educator and community competencies, cooperation and mutual awareness. This can be applied in education. The importance of developing intellectual capital in the educational environment needs to be explained again how a teacher is able to develop intellectual capital to improve its performance.

Thus intellectual capital is an important part that must be owned by the teacher. This statement is supported by Kelly's assessment (2014: 609) which confirms that:

"The key human intellectual capital in schools include:

a) competency capital, or the skills and know-how of teachers and administrators; b) attitude capital, which comprises motivation, strategic intent and work ethics; and c) intellectual agility, which entails the ability of teachers, administrators and students to innovate and change practices when problems arise."

In the industrial 4.0 era teachers as educational leadership in schools are required to express reflected professional competencies in three forms of capital namely intellectual capital, social capital and organizational capital, in building effective schools. A school that effectively mobilizes capital to achieve educational outcomes. Intellectual capital refers to the resources of the collective knowledge produced and experienced in school between school members to improve the quality of graduates. The quality of graduates of a school is determined by the intellectual competencies possessed by the teacher, namely the character and attitude or willingness and ability of the individual intellectual (can be knowledge, skills, professional understanding, contextual understanding) that are relatively stable when dealing with problems in the workplace, which are formed from synergy between character, self-concept, internal motivation, and contextual knowledge capacity. This intellectual competence is internalized in the form of nine competencies (Spencer \& Spencer, 2013: 35) as follows: 1) Achievement, 2) Job satisfaction 3) Initiative, 4) Mastery of Information 5) Analytical Thinking, 6) Practical Skills, 7) Conceptual Thinking, 8) Linguistic Ability and 9) Narrative Ability.

Teachers, in this case, are referred to as Human Resources which have an important and dominant role in an educational institution at the high school level. Therefore intellectual capital that has been owned by the school needs to be maintained and developed its quality. In principle, the goal of teacher intellectual capital is to create quality graduates who are able to compete competently in the outside world. Thus the management of good intellectual capital is expected to be able to improve teacher performance in high school.

In the public sector, especially for senior secondary education, there are very few studies related to the development of intellectual capital. In fact, high school education is considered as an institution that plays an important role in the secondary education system. The main purpose of education is to produce and disseminate knowledge, and the most important investment for high school education is in the human resource development sector which is an important part of intellectual capital (Yuniningsih, 2017). The scope of the limitation in this study is intellectual capital developed by the teacher using the opinion of Burr \& Girardi (2012: 77), with dimensions: Competence, Commitment, and work control. From these problems, the purpose of this study is to express the form of intellectual capital developed by economic teachers in Pontianak City High School in order to improve the quality of graduates, especially the quality of the value of economic subjects.

\section{RESEARCH METHOD}

This research is a qualitative descriptive study that there is not special treatment on the variables studied. Qualitative descriptive techniques are used to process findings data in research activities carried out. The subjects of this study were public high school economics teachers in the city of Pontianak. The object of research is the intellectual capital developed by economic teachers in public high schools. Data in research uses two types of data, namely primary data and secondary data. Primary data was collected from Pontianak state high school economics teachers, while secondary data was collected by students. Data collection techniques used are interviews, observation and documentation and field notes/log books. The instruments of data collection are interviews and observations. Data analysis includes data managing, reading, and memorizing, describing, classifying, interpreting, and visualizing.

\section{RESULTS AND DISCUSSION}

\section{A. Results}

Based on the results of data collection on the object of research in Pontianak City High School concerning 
Intellectual capital developed by economic teachers, the following data were obtained.

TABLE I

CHARACTERISTICS OF INFORMANTS BASED ON SCHOOL ACCREDITATION STATUS

\begin{tabular}{clcc}
\hline No & Alternative Answers & Frequency & Percentage (\%) \\
\hline 1 & A Accreditation & 10 & 100 \\
2 & B Accreditation & - & - \\
\hline & Total & 10 & 100 \\
\hline
\end{tabular}

TABLE III

CHARACTERISTICS OF INFORMANTS BASED ON EDUCATION LEVEL

\begin{tabular}{cccc}
\hline No & Alternative Answers & Frequency & Percentage (\%) \\
\hline 1 & Bachelor degree (S1) & 7 & 70 \\
2 & Postgraduate (S2) & 3 & 30 \\
\hline & Total & 10 & 100 \\
\hline
\end{tabular}

TABLE IIIII

CHARACTERISTICS OF INFORMANTS BASED ON WORKING PERIOD

\begin{tabular}{cccc}
\hline No & Alternative Answers & Frequency & Percentage (\%) \\
\hline 1 & $10-15$ Years & 5 & 50 \\
2 & $16-21$ Years & 1 & 10 \\
3 & $22-27$ Years & 4 & 40 \\
\hline & Total & 10 & 100 \\
\hline
\end{tabular}

TABLE IVV

CHARACTERISTICS OF INFORMANTS BASED ON HAVING EDUCATOR CERTIFICATES

\begin{tabular}{|c|c|c|c|}
\hline No & Alternative Answers & Frequency & Percentage (\%) \\
\hline 1 & $\begin{array}{l}\text { Have an Educator } \\
\text { Certificate }\end{array}$ & 10 & 100 \\
\hline 2 & Do not have a certificate & - & - \\
\hline & Total & 10 & 100 \\
\hline
\end{tabular}

TABLE V

DEVEloping INTELLECTUAL CAPITAL DEVELOPED By ECONOMiC TEACHERS

\begin{tabular}{clccccc}
\hline No & $\begin{array}{c}\text { Alternative } \\
\text { Answers }\end{array}$ & $\begin{array}{c}\text { Very } \\
\text { good }\end{array}$ & Good & $\begin{array}{c}\text { Pretty } \\
\text { good }\end{array}$ & $\begin{array}{c}\text { Not } \\
\text { good }\end{array}$ & Total \\
\hline 1 & $\begin{array}{l}\text { Intellectual } \\
\text { Competence }\end{array}$ & 8 & 2 & - & - & 10 \\
& $\begin{array}{l}\text { Emotional } \\
\text { Competence } \\
\text { Social }\end{array}$ & 3 & 6 & 1 & - & 10 \\
2 & 7 & 2 & 1 & - & 10 \\
$\begin{array}{l}\text { Competence } \\
\text { Affective }\end{array}$ & 5 & 4 & 1 & - & 10 \\
$\begin{array}{l}\text { Commitment } \\
\text { Relational } \\
\text { Commitment }\end{array}$ & 4 & 4 & 2 & - & 10 \\
& $\begin{array}{l}\text { Normative } \\
\text { Commitment }\end{array}$ & 2 & 2 & 5 & 1 & 10 \\
3 & Job Control & 2 & 6 & 1 & 1 & 10 \\
\hline
\end{tabular}

Based on the results of interviews and observations of intellectual capital developed by economic teachers at Pontianak City Public High School, they include:

a. Intellectual Competencies Developed by Economic Teachers
From the research, it was revealed that the intellectual competencies possessed by economic teachers were very good categories and were developed by teachers through MGMP activities that were always carried out by all teachers once a month in turns at school. In this activity, the teacher discusses some economic material that is considered difficult and looks for learning strategies together to improve student learning outcomes. This activity is only limited to fellow teachers and has never been brought in from outside parties. In competencies among teachers, many are based on teacher competencies in mastering their respective fields. Each teacher believes that the teacher who teaches in a Public High School has qualified as a teacher based on a diploma that all teachers have an academic qualification in accordance with the field of study and 70\% of graduates in Economics and $30 \%$ Masters in Education in Economic Education, and all have educator certificates. The results of the observations show the ability of several economics teachers in implementing learning and practicing economic material through the application of cooperative activities.

\section{b. Emotional Competencies developed by Economic} Teachers

From the research, it was revealed that the emotional competencies possessed by economic teachers were in a good category and were developed by the teacher through mutual respect, adjusting and helping to complete the work assigned by the boss to fellow teachers. In the process of economic learning, there are still some teachers who have not developed emotional competence well. This occurs in some economic teachers who have a relative tenure of 10-15 years.

c. Social Competencies Developed by Economic Teachers

From the research, it was revealed that the social competencies possessed by economic teachers were in a good category and were developed by teachers through mutual building attitudes and maintaining a network of cooperation among fellow economic teachers to remain intimate and warm by forming a family of economic teacher families. In addition, it also develops specific feedback to students regarding material to improve learning outcomes through social media. The form of social competence for students is done by receiving communication services with students through WhatsApp. This activity is mostly carried out by economic teachers who are relatively young and new tenure ranges from 10 years. Whereas for a period of work that is relatively long in communication about learning with students is only enough at school.

d. Affective Commitments developed by Economic Teachers

From the research, it was revealed that the affective commitment of the average economic teacher was good and was developed through trust in the PGRI organization as part of his life and spent his life teaching at the school. They always follow the activities carried out by PGRI to fight for their destiny to maintain a decent life as a teacher. Likewise in economic learning, most economic teachers already have a 
commitment to enforce rules such as building commitment together with students in learning.

\section{e. Relational Commitments Developed by Economic Teachers}

From the research, it was revealed that the relational commitment possessed by economic teachers was on average good and was developed through an attitude of loyalty to his work as an economic teacher where they felt disturbed when delaying work, especially until they did not enter teaching. In addition, they also develop it through loyalty to the leaders and the schools where they serve.

\section{f. Normative Commitments Developed by Economic Teachers}

From the research, it was revealed that the normative commitment possessed by economic teachers on average was quite good and was developed through a sufficient attitude to obey the rules in carrying out work and enough to try to remain at the school even in uncomfortable conditions.

\section{g. Job Control Developed by Economic Teachers}

From the research, it was revealed that the control of work owned by economic teachers was on average good and was developed through the means of independence and freedom of the teacher in making learning plans, controlling the learning process and decision making during the learning process.

\section{B. Discussion}

Based on the results of interviews and observations made at the Pontianak City Public High School economics teacher, the form of intellectual capital developed to improve intellectual competence is in the form of MGMP activities that take place once a month by economic teachers in school. In this activity, there are several economics teachers discussing some economic material that is considered difficult and looking for learning strategies together to improve student learning outcomes. This activity is only limited to fellow teachers and has never brought in from outside parties, such as bringing in lecturers in the field of study to participate in dissecting material and learning strategies from experts. In competencies among teachers, many are based on teacher competencies in mastering their respective fields. This is in line with the opinion of Nahapiet \& Ghoshal (Subhan, 2014: 245) saying:

"Intellectual competence is the character of attitudes and behaviors or willingness and intellectual abilities of individuals (can be in the form of knowledge, skills, professional understanding, contextual understanding, etc.) that are relatively stable when dealing with problems in the workplace, which are formed from the synergy between character, concept self, internal motivation, and contextual knowledge capacity."

Each student believes that the teacher who teaches in the Public High School has fulfilled the qualifications as a teacher based on a diploma that is owned by all economic teachers who have $70 \%$ of Education degrees and 30\% of Masters in Education in Economic Education, and all have educator certificates. The results of the observations show the ability of several economics teachers in implementing learning and practicing economic material through the application of cooperative activities.

Based on the results of observations and interviews on emotional competencies developed by economic teachers through mutual respect, adjusting and helping to complete the work assigned by supervisors to fellow teachers. In the process of economic learning, in general, the attitude developed by economic teachers teaches students to respect each other and help each other friends in economic learning while doing exercises in the classroom and doing homework. In line with the opinion of Goleman (2015:410) also emphasizes that emotional competence as an ability to recognize and manage emotions themselves well, able to recognize the emotions of others, and be able to establish positive relationships with others in order to produce a performance on a particular job. However, in some schools, there are still economic teachers who have not developed emotional competence well. This happened to some economic teachers who relatively had a 5-10 year working period with a relatively younger age.

Based on the results of observations and interviews of social competencies developed by teachers through mutual building attitudes and maintaining a network of cooperation among fellow economic teachers to remain intimate and warm by forming a family gathering of economic teachers. This is supported by the opinion of Spencer \& Spencer, (2013: 39). Social competence is a character of attitude and behavior or willingness and ability to build nodes of cooperation with other people who are relatively stable when facing problems in the workplace that are formed through synergies between character, self-concept, internal motivation, and social knowledge capacity. In addition, it also develops specific feedback to students regarding material to improve learning outcomes through social media. The form of social competence for students is done by receiving communication services with students through Wathchap. Based on the results of student interviews, this activity is mostly carried out by economic teachers who are relatively young and have a new tenure of 10 years. Whereas for a period of work that is relatively long in communication about learning with students is only enough at school.

Based on the results of observations and interviews of affective commitments developed by economic teachers through trust in the PGRI organization as part of his life and spent his life teaching at the school. This is in line with Hornby (Nur'aeni, 2011: 109) saying that commitment is a willingness to work hard and provide energy and time for a job or activity. They always follow the activities carried out by PGRI to fight for their destiny to maintain a decent life as a teacher. Likewise in economic learning, most economic teachers already have a commitment to enforce rules such as building a joint commitment with students in learning to enforce discipline in the classroom and sanction students who are late in entering by standing in front of the class and not allowed to sit and do economic assignments to collected tomorrow. 
Based on the results of observations and interviews that relational commitment developed by economic teachers through being loyal to their work as economic teachers where they feel disturbed when delaying work, especially until they do not enter teaching. In addition, they also develop it through loyalty to the leaders and the schools where they serve. Burr and Girardi (Narimawati, 2011: 152) emphasize that relational commitment is a feeling of love for an organization because employees value the number of costs sacrificed if they leave the organization.

Based on the results of the interview and the observation that the normative commitment developed by the economic teacher through the attitude enough to comply with the rules in carrying out work and enough to try to remain at the school even in uncomfortable conditions. This attitude is shown by economic teachers in the learning process by always adhering to the rules set by the school. In line with the opinion of Burr and Girardi (2012: 80), it is emphasized that normative commitment is a reflection of the feeling of compulsory workers to stay with the organization.

Based on the results of interviews and observations developed by economic teachers in controlling work through the means of independence and freedom of teachers in making learning planning as well as the preparation of RPP in determining indicators, controlling the learning process through classroom management so that the implementation of learning is more directed. While decision-making when the learning process is developed through the determination of methods, learning models and media determined by the economic teacher independently. This was confirmed by Robbins (Kori et al., 2016:3). Work schedule is a plan that records all the work that is owned by workers and when each job must be done, while the procedure is a way to do work that prioritizes the usual or right way, such as: keeping procedures, following normal/standard procedures/generally accepted, and resolve complaints with a simple procedure.

\section{CONCLUSION}

Intellectual capital developed by economic teachers at Pontianak City State Senior High School is in the form of competencies, namely MGMP activities which are always carried out by teachers once a month in turns at school. Mutual respect, adjusting and helping to complete the work assigned by the Principal to the teacher. Whereas in the form of commitment is trust in the organization of the Teachers Association of the Republic of Indonesia (PGRI) as part of its life and an attitude of loyalty to its work as an economics teacher. To control the work developed by the economic teacher by building the independence and freedom of the teacher in making learning plans, controlling the learning process and decision making during the learning process.

\section{REFERENCES}

Burr, R., and Girardi, A. (2012). Intellectual Capital: More Than The Interaction of Competence x Commitment. Australian Journal of Management. Sydney. p. 7778.

Djaali. (2012). Human Resource Development Through Education. Jakarta. UNJ. Posted.

Goleman, Daniel. (2015). Emotional Intelligence, Mengapa EI Lebih Tinggi daripada IQ. Jakarta: PT. Gramedia Pustaka Utama

Kelly, A. (2014). The intellectual capital of schools: Analyzing government policy statements on school improvement in light of a new theorization. Journal of Educational Policy, 19(5).

Kori, K.A.N.J., Susila. G.P.A.J, and Bagia. I.W. (2016). Effect of Job Control and Job Satisfaction on Employee Performance. E-journal Bisma Universitas Pendidikan Ganesha Jurusan Manajemen, 4. https://ejournal.undiksha.ac.id/index.php/jjm/article/v iew/6716/4577

Narimawati. U. (2011). The Role of Lecturer Intellectual Capital in Creating Graduates Quality. Jurnal Majalah Ilmiah Unikom, 6(2). https://jurnal.unikom.ac.id/jurnal/peranan-modalintelektual.7

Nur'aeni. (2011). The Influence Of Motivation, Competence And Commitment On Lecturer's Performance At Private Higher Education In Kopertis Regional II Palembang (Survey On Private Higher Education In Kopertis Regional II Palembang). Jurnal Manajemen dan Bisnis, 1(2), 101-129.

Spencer, L. M., and Spencer, S. M. (2013). Competence at Work. New York, John Willey \& Sons.

Subhan, M. (2014). The Effect of Risk and Competence Knowledge on Underwriters' Performance in the Insurance Industry (General) in Indonesia. Jurnal MIX, $4(1)$. http://publikasi.mercubuana.ac.id/index.php/Jurnal_ Mix/article/view/107

Sukarno, Gendut and Adriyanfitri, Helmia. (2016). Intellectual Capital Teachers in Some Private High Schools in Sidoarjo. MEBIS JOURNAL. Management and Business Management Study Program, National Veterans Development University ISSN: 2599-283X (Online) ISSN: 2528-2433 (Print), page 61.

Sung-Choon Kang and Scott A. Snell. (2005). Intellectual Capital Architectures and Bilateral Learning: A Framework For Human Resource Management. USA. Cornell University ILR School.

Yuniningsih, Y. (2017). How Big Share Ownership Role In Determining Corporate Values With Agency Theory Review. Jurnal Darussalam: Journal of Education, Communication, and Thought of Islamic Law, 9(1), 107-115. Available at: Http: // ejournal. iaida. air conditioning. id / index. php / darussalam / article / view / 120 (Accessed: 30 October 2017). 